\title{
Akciğer Kanserli Hastalarda F-18 FDG PET/BT Parametrelerinin Klinik Evre ile İlişkisi
}

\section{The Relationship Between F-18 FDG PET/CT Parameters and Clinical Stage in Patients with Lung Cancer}

Mustafa Erol ${ }^{1}$,

Hasan Önner ${ }^{1}$,

Güngör Taştekin²,

${ }^{1}$ Sağlık Bilimleri Üniversitesi, Konya Eğitim ve Araştırma Hastanesi, Nükleer Tıp Birimi, Konya, Türkiye

${ }^{2}$ Necmettin Erbakan Üniversitesi, Meram Tıp Fakültesi, Nükleer Tıp Anabilim Dalı, Konya, Türkiye

Geliş Tarihi/Received: 04 Mart 2020 Kabul Tarihi/Accepted: 09 Mayıs 2020

Yazışma Adresi: Mustafa Erol, Sağlık Bilimleri Üniversitesi, Konya Eğitim ve Araştırma Hastanesi, Nükleer Tıp Birimi, Konya, Türkiye e-posta: mustafaerol82@hotmail.com

\section{ORCID}

Mustafa Erol

https://orcid.org/0000-0003-3121-5330 Hasan Önner

https://orcid.org/0000-0003-1002-2097 Güngör Taştekin

https://orcid.org/0000-0002-8895-5359
Öz

Amaç: Bu çalışmada akciğer kanserinin pozitron emisyon tomografi/bilgisayarlı tomografi (PET/BT)'den elde edilen primer lezyonun en geniş çapı (LEGÇ), maksimum standardize alım değeri (SUVmax), ortalama standardize alım değeri (SUVmean), metabolik tümör hacmi (MTV) ve toplam lezyon glikolizis (TLG) değerlerinin klinik evre ile ilişkisi incelenecektir.

Hastalar ve Yöntem: Necmettin Erbakan Üniversitesi Meram Tıp Fakültesi Nükleer Tıp Anabilim Dalında 01.01.2012- 31.12.2014 tarihleri arasında PET/BT görüntülemesi yapılan, akciğer kanseri tanılı hastalar çalışmaya alındı. PET/BT görüntülerinden elde edilen LEGÇ, SUVmax, SUVmean, MTV ve TLG değerleri ile histopatolojik alt tipler not edildi. Küçük hücre dışı akciğer kanseri (KHDAK) tanısı alan hastalar TNM (Tümör boyutu, lenf nodu, uzak metastaz) evreleme sistemi ile evrelendirildi. Küçük hücreli kanser (KHAK) tanısı alanlar sınırlı ya da yaygın evre olarak sınıflandırıldı.

Bulgular: Yüz on sekizi erkek ve 12'si kadın toplam 130 hastanın, ortalama yaşı $63,46 \pm 9,96$ idi. Yüz altı hasta $(\% 81,5)$ KHDAK iken; $24(\% 18,5)$ hastaya KHAK idi. KHDAK hastaların 62 'si yassı hücreli kanser, 39'u adenokanser, 5'i diğer alt tiplerden olussmaktaydı. PET/BT görüntülerinden elde edilen LEGC, SUVmean, SUVmax'ın ortalama değerlerinin, MTV ile TLG'nin ortanca değerlerinin KHDAK ile KHAK hasta grupları arasında anlamlı fark yoktu. Ayrıca bu parametrelerin KHAK'de evre ile ilişkisinin olmadığı da bulundu. KHDAK'de LEGÇ, SUVmax, SUVmean, MTV ve TLG parametrelerinin klinik evre ile ilişkili olduğu saptandı.

Sonuç: Küçük hücreli dışı akciğer kanserinde yüksek SUVmax, SUVmean, MTV ve TLG değerleri ileri klinik evreyi predikte etmektedir.

Anahtar Kelimeler: Akciğer kanseri, pozitron emisyon tomografi, standardize alım değeri, metabolik tümor volümü, toplam lezyon glikolizi.

\section{Abstract}

Aim: It was aimed to investigate the relationship of disease clinical stage between the maximum diameter of primer lesion (MDPL), maximum of standardized uptake value (SUVmax), mean of standardized uptake value (SUVmean), metabolic tumor volume (MTV) and total lesion glycolysis (TLG) values derived from positron emission tomography/computed tomography (PET/CT).

Patients and Methods: Lung cancer patients diagnosed histopathologically between 01.01 .2012 and 31.12.2014 in Necmettin Erbakan University Nuclear Medicine Department of Meram Medical Faculty scanned for PET/CT for lung cancer diagnosis and staging, were included in this study. MDPL, SUVmax, SUVmean, TLG and MTV derived from PET-CT scanning and their histopathological subtypes, other clinical and radyological information of patients were noted. The non-small cell lung cancer (NSLC) were graded according to tumor diameter, nodal and involvement metastasis (TNM) staging system. The small cell lung carcinoma (SCLC) diagnosed were categorised as limited or extensive stage.

Results: In this study, the mean age of 118 men and 12 women, totally 130 patients, was evaluated 63,46 $\pm 9,96$. The patients were classified as 106 NSCLC $(81.5 \%)$ ve 24 SCLC $(18.5 \%)$. The histopathologically diagnosed NSCLC patients were consists of 62 squamous cell cancers, 39 adeno cancers, and 5 other subtypes. It was observed that there was no significant relationship between the MDPL, SUVmax, SUVmean, MTV and TLG values among SCLC. Additionally, it was also found that there was no correlation between these parameters with the SCLC stage. MDPL, SUVmax, SUVmean, MTV and TLG parameters were related with stage in NSCLC patients.

Conclusion: Higher SUVmax, SUVmean, MTV, and TLG values of the primary tumor were predicting the more advanced clinical stage in NSCLC.

Key words: Lung cancer, positron emission tomography, standardized uptake value, metabolic tumor volume, total lesion glycolysis.
Atıf yapmak için: Erol M, Önner H, Taştekin G. Akciğer Kanserli Hastalarda F-18 FDG PET/BT Parametrelerinin Klinik Evre ile İlişkisi. Selcuk Med J 2021;37(1): 24-31
Açıklama: Yazarların hiçbiri, bu makalede bahsedilen herhangi bir ürün, aygıt veya ilaç ile ilgili maddi çıkar ilişkisine sahip değildir. Araştırma, herhangi bir dış organizasyon tarafından desteklenmedi. Yazarlar çalışmanın birincil verilerine tam erişim izni vermek ve derginin talep ettiği takdirde verileri incelemesine izin vermeyi kabul etmektedirler. 


\section{GíRiş}

Akciğer kanseri tüm dünyada erkeklerde en sık teşhis edilen kanser olup kansere bağlı ölümlerin en sık sebebidir. Kadınlarda ise üçüncü sıklıkta teşhis edilen kanser olup ikinci sıklıkta ölüme neden olan kanser türüdür (1). Uluslararası Akciğer Kanseri Çalışma Derneği'nin (IASLC) tümör, lenf nodu, metastaz (TNM) evreleme sisteminin 7. versiyonuna göre sağkalım oranları incelendiğinde evre IA'da \%50 olan 5 yıllık sağkalım oranı evre IV'de \%2'ye düşmektedir (1). Erken evre küçük hücreli akciğer kanserinde (KHAK) ise en yüksek 5 yıllık sağkalım oranı \%38'dir (2). Böylesine önemli bir kanser türünde tedavinin planlanması, takibi ve prognozu tahmin etmek için bazı faktörlere gereksinim vardır. Her ne kadar TNM evrelendirme sistemi prognozu belirlemede en çok kabul edilen ve üzerinde çalışılmış prognoz belirteci olsa da aynı evrede olan hastalardaki farklı prognozu açıklayamamaktadır (3). Tümör büyüme hızı ile tümörün florodeoksiglukoz (FDG) tutulumu arasında korelasyon saptanması ve immunhistokimyasal olarak transmembran glukoz taşıyıcılarının (Glut 1 ve Glut 3) aşırı üretiminin kötü prognozla ilişkisinin gösterilmesi, prognostik faktör olarak FDG tutulumunun araştırılmasına aracı olmuştur (4, 5). Ahuja et al. (6) evre I-IV arası 155 küçük hücreli dışı akciğer kanseri (KHDAK) hastasıyla yaptıkları çalışmada aynı evrelerdeki farklı FDG tutulumuna sahip hastaların yaşam sürelerinin farklı olduğunu belirtmişler ve primer tümörü yüksek FDG tutulumu gösteren hastaların sağ kalımlarının daha kısa olduğunu ileri sürmüşlerdir.

Tümör TNM evrelemesinin maksimum standardize alım değeri (SUVmax) ile ilişkisini içeren çalışmalar da yapılmıştır. Cerfolio et al. (7) 315 KHDAK'ı hastayı kapsayan çalışmalarında TNM evrelemesine göre evre I-IV arasındaki hastalarda farklı derecelerde SUVmax değeri olduğunu ve bu farklılığın istatistiksel açıdan anlamlı olduğunu bulmuşlardır. Başka bir çalışmada Li et al. (8) değişik histolojilerde, evre I-IV arasında, tümör boyutları 0,9-3,0 cm arasında olan 107 adet KHDAK hastayı retrospektif olarak incelemişlerdir. Bu çalışma sonunda tümör boyutu ile SUVmax arasında pozitif korelasyon saptamışlardır (8). Ayrıca son zamanlarda PET/BT tetkiklerinde hesaplanabilen ve bazı çalışmalarda KHDAK hastalarında, hastanın TNM evresinden bağımsız prognostik faktör olarak değerlendirilen metabolik tümör hacmi (MTV) ve toplam lezyon glikolizisi (TLG) gibi parametreler de değerlendirilebilmektedir. MTV lezyon çevresine çizilen ilgi alanı (ROI) içinde kalan üç boyutlu toplam hacmi göstermektedir. TLG ise bu ilgi alanı içerisindeki hem metabolik aktiviteyi hem de glikolitik aktiviteyi birlikte yansıtan bir parametredir. Liao et al. (9) tarafından yapılan bir çalışmada preoperatif KHDAK hastalarında MTV ve TLG değerleri ile genel sağkalım arasında anlamlı ilişki gösterilmiştir). Yapılan başka bir çalışmada erken evre KHDAK hastalarında MTV ve TLG değerlerinin sağkalım için bağımsız prognostik faktörler olduğu saptanmıştır (10).

Pozitron emisyon tomografi/bilgisayarlı tomografi (PET/BT) görüntülemesi akciğer kanserinin tanısında, evrelemesinde, tedavi yanıtının değerlendirilmesinde ve prognozu öngörmedeki başarısı nedeniyle giderek daha fazla kullanılan, etkin, invazif olmayan bir görüntüleme yöntemi olarak günümüzde rutin klinik kullanımda yerini almıştır. PET/BT metastatik yayılımı göstermedeki üstün yanlarının yanı sıra tümördeki metabolik aktiviteyi göstererek hastalığın biyolojik saldırganlığı ve prognozu ile ilgili ek bilgi sağlamaktadır.

Tüm bu bilgiler ışığında çalışmamızda, akciğer kanserli hastaların TNM evreleri ile PET/BT görüntüleme bulguları [lezyonun en geniş çapı (LEGÇ), SUVmax, ortalama standardize alım değeri (SUVmean), MTV ve TLG değerleri] arasındaki ilişki araştırıldı.

\section{HASTALAR VE YÖNTEM}

$\mathrm{Bu}$ çalışmaya Necmettin Erbakan Üniversitesi Meram Tıp Fakültesi Etik Kurulu'ndan 27.04.2015 tarihinde 2015/192 sayılı karar ile onay alındı.

Necmettin Erbakan Üniversitesi Meram Tıp Fakültesi Nükleer Tıp Anabilim Dalı'nda 01.01.2012 ile 31.12.2014 tarihleri arasında akciğer kanseri tanısı ve evreleme amacıyla PET/BT görüntülemesi yapılan toplam 130 hasta çalışmaya dahil edildi. Akciğer kanseri tanısı ve evrelemesi amacıyla PET/ BT tetkiki yapılmış, histopatolojik olarak KHAK veya KHDAK tanısı doğrulanmış, tetkik öncesinde kan glukoz düzeyleri 150 mg/dl'nin altında olan hastalar çalışmaya dahil edildi. Daha önceden bilinen başka bir kanser öyküsü olan, tetkik öncesinde akciğer kanseri nedeniyle opere olan ve daha önceden kemoterapi (KT) ve radyoterapi (RT) alan hastalar çalışma dışı bırakıldı.

Ayrıca hastaların yaş, cinsiyet, kan glukoz düzeyleri, histopatolojik tipleri ve mevcut ise hastaların sigara kullanım öyküsüne ait bilgileri kaydedilmiştir. KHDAK tanısı alan hastalar klinik bilgileri, PET/BT ve varsa diğer radyolojik tetkik sonuçları kullanılarak 
TNM sistemine göre; KHAK tanısı alanlar ise sınırlı ya da yaygın evre olarak evrelendirildi.

\section{PET/BT Görüntüleme Protokolü}

Hastalar PET/BT görüntüleme öncesi en az 6 saat aç olarak çağrıldı. Radyofarmasötik enjeksiyonu öncesi kan glukoz düzeyi 150 mg/dL'nin altında olan hastalara 8-15 mCi FDG'nin intravenöz yoldan enjeksiyonundan 1 saat sonra verteks-1/3 uyluk proksimali arası PET/BT görüntüleme yapıldı. PET/ BT görüntüleri iki nükleer tıp uzmanı tarafından değerlendirildi. Fizyolojik tutulum alanları dışında zemin aktivitesine oranla artmış FDG tutulumu (SUVmax değeri 2,5 ve üzeri) gösteren odaklar pozitif lezyonlar olarak değerlendirildi. Çalışmaya dahil edilen hastaların primer tümörlerinin tamamını içine alacak ilgi alanları çizilip, SUVmax, SUVmean, MTV ve TLG değerleri not edilmiştir. İlgi alanına varsa tümörün periferindeki konsolidasyon alanı ve yakın komşuluktaki lenf nodları mümkün olduğunca dahil edilmemeye çalışıldı.

\section{Kantitatif Parametrelerin (SUVmax, SUVmean, MTV ve TLG) Hesaplanması}

Dokulardaki FDG tutulumunun kantitatif ölçümleri olan SUV değerleri PET görüntülerinden hesaplanan dokuların benign/malign olarak ayırımını değerlendirmede kullanılan yarı kantitatif bir parametredir. Seçilmiş bir ilgi alanı içerisindeki aktivitenin $(\mathrm{mCl} / \mathrm{mL})$ ) enjekte edilen doza (mCi/ $\mathrm{kg}$ ) bölünmesi ile SUV değeri elde edilir. Klinik uygulamada SUVmax en yaygın kullanılan tipi olup çizilen ilgi alanı içerisindeki maksimum FDG tutulumunu göstermektedir.

Metabolik tümör hacmi PET/BT de seçilen bir ilgi alanı içerisindeki tümörün metabolik yükünü yansıtmaktadır. Seçilen ilgi alanı içerisindeki aktivitenin \%42 eşik değeri belirlenerek yazılım tarafından otomatik olarak hesaplanmaktadır. TLG ise hem metabolik aktiviteyi hem de glikolitik aktiviteyi birlikte yansıtmakta olup aşağıda formülüze edildiği gibi MTV ile SUVmean değerlerinin çarpılması ile hesaplanmaktadır.

[TLG=SUVmean X MTV $\left(\mathrm{cm}^{3}\right)$ ]

\section{Veri Tabanı ve İstatistiksel Analiz}

Veriler SPSS 20.0 programı ile analiz edildi. KHAK ve KHDAK hasta grupları arasında hastaların demografik verileri ve PET/BT bulguları bakımından karşılaştırmalar yapıldı. Verilerin normal dağılım gösterip göstermediği Kolmogorov-Smirnov testi ile değerlendirildi. Normal dağılım varlığında parametrik testler; parametrik ikili gruplarda Student t-testi, çoklu gruplarda tek yönlü varyans analizi testi kullanıldı.
Normal dağılım gözlenmediği durumda ise nonparametrik testler (ikili gruplarda Mann-Whitney $U$ testi, çoklu gruplarda Kruskall Wallis varyans analizi) kullanıldı. İstatistiksel anlamlılık bakımından eşik değeri $p<0,05$ olarak kabul edildi.

\section{BULGULAR}

\section{Hastaların Demografik Bilgileri}

Çalışmaya dahil edilen toplam 130 hastanın 118'i erkek, 12'si kadın olup, ortalama yaş 63,46 \$ 9,96 (4087 yaş) olarak bulunmuştur. Hastalar histopatolojik olarak sınıflandırıldığında 24'ü $(\% 18,5)$ KHAK, 106'sı $(\% 81,5)$ KHDAK'dir. KHDAK hastalarının da 62'si yassı hücreli kanser $(\% 47,7)$, 39'u adenokanser $(\% 30,0)$, 5'i diğer $(\% 3,8)$ (3 karsinoid tümör, 1 büyük hücreli ve 1 sarkomatoid tümör) histopatolojik tanılardan oluşmaktaydı. KHAK hastalarının 16'sında sınırlı hastalık, 8'inde yaygın hastalık saptanmıştır. Küçük hücreli dışı akciğer kanseri tanısı alan hastaların 7'sinde evre IA, 4'ünde evre IB, 5'inde evre IIA, 8'inde evre IIB, 23'ünde evre IIIA, 21'inde evre IIIB ve 38'ünde evre IV hastalık saptanmıştır. Çalışmaya dahil edilen hastaların demografik bulguları tablo 1'de sunulmuştur. Şekil 1'de skuamöz hücreli akciğer kanseri bir hastanın transaksiyel eksende FDG PET/ BT görüntüsü ve bulguları verilmiştir.

\section{Pozitron Emisyon Tomografi /Bilgisayarlı Tomografi Bulguları}

Küçük hücreli akciğer kanseri ile KHDAK hasta grupları arasında evre farkı gözetilmeksizin yapılan karşılaştırmada; LEGÇ, SUVmax, SUVmean parametrelerinin ortalama değerlerinde, MTV ile TLG'nin median değerlerinde KHAK ile KHDAK hasta grupları arasında istatistiksel olarak anlamlı farklılık saptanmadı. KHAK ile KHDAK hastalarının evre farkı gözetilmeksizin PET/BT bulguları tablo 2'de sunulmuştur.

Küçük hücreli akciğer kanserinde sınırlı evre ile yaygın evre KHAK hastaları arasında; LEGÇ, SUVmax, SUVmean parametrelerinin ortalama değerlerinde, MTV ile TLG'nin medyan değerlerinde istatistiksel olarak anlamlı farklılık saptanmadı. KHAK hastalarının evrelerine göre PET/BT bulguları tablo 3'de sunulmuştur.

Küçük hücreli dışı akciğer kanserli hastalarda SUVmax, SUVmean, MTV ve TLG yönünden farklı T evreleri arasında anlamlı farklılık saptanmış $(p<0,05)$ olup T evresi arttıkça SUVmax, SUVmean, MTV ve TLG değerlerinde artış gözlendi.

Küçük hücreli dışı akciğer kanserli hastalarda farklı N evreleri arasında; LEGÇ, SUVmax, SUVmean, MTV 
Tablo 1. Akciğer Kanserli Hastaların Demografik Bilgileri

\begin{tabular}{llll}
\hline & KHDAK & KHAK & Toplam \\
\hline Hasta sayısı $(\mathrm{n})$ & 106 & 24 & 130 \\
Yaş (ortalama & $63,75 \pm 9,84$ & $62,21 \pm 10,56$ & $63,46 \pm 9,96$ \\
Cinsiyet (erkek/kadın) & $95 / 11$ & $23 / 1$ & $118 / 12$ \\
Sigara kullanımı & $76(\% 71)$ & $18(\% 75)$ & $94(\% 72)$ \\
\hline
\end{tabular}

ve TLG yönünden anlamlı farklılık saptandı $(p<0,05)$. Yapılan ikili karşılaştırmada; N0 ile N2, N0 ile N3, N1 ile N2 ve N1 ile N3 evreleri arasında anlamlı farklılık saptandı $(p<0,05)$.

Küçük hücreli dışı akciğer kanserli hastalarda farklı klinik evreleri arasında; LEGÇ, SUVmax, SUVmean, MTV ve TLG yönünden anlamlı farklılık saptandı $(p<0,05)$. Yapılan ikili karşılaştırmada; evre 1 ile evre $3 A$, evre $3 B$ ve evre 4 arasında, evre 2 ile evre $3 A$ ve evre 3B ile evre 4 arasında anlamlı farklılık saptandı $(p<0,05)$. KHDAK hastaların evrelerine göre PET/BT bulguları tablo 4'de sunulmuştur.

\section{TARTIŞMA}

Akciğer kanseri, tüm dünyada erkeklerde en sık, kadınlarda ise ikinci sıklıkta ölüme neden olan kanser türüdür. Ayrıca tüm kanserler içinde \%11,6 oranında görülme sıklığına sahip olup, kansere bağlı ölümlerinin \%18,4'ünden sorumludur (11) Böylesine önemli bir kanser türünün tedavi planlanmasını, takibini ve prognozunu öngörmek için bazı faktörlere gereksinim vardır. Her ne kadar TNM evreleme sistemi prognozu belirlemede en çok kabul edilen belirteç olsa da aynı evrede olan hastalardaki farklı prognozu açıklayamamaktadır $(3,12)$.

Pozitron emisyon tomografi/bilgisayarlı tomografi görüntülemesi akciğer kanserinin tanısında, evrelemesinde, tedavi yanıtının değerlendirilmesinde ve prognostik faktörleri öngörmedeki başarısı nedeniyle giderek daha fazla kullanılan invazif olmayan bir görüntüleme yöntemi olarak rutin klinik kullanımda yerini almıştır (13). Bu görüntüleme yönteminden elde edilen SUVmax, MTV ve TLG gibi farklı fonksiyonel parametrelerin prognostik faktörler ile ilişkisi çalışmalarda gösterilmiştir (9, 1315). Çalışmamızda, KHDAK hastalarında klinik evre ile PET/BT bulgularını (LEGÇ, SUVmean, SUVmax, MTV ve TLG değerleri) ve KHAK'nde sınırlı ve yaygın evre ile PET/BT bulgularını karşılaştırdık. Ayrıca KHAK ile KHDAK gruplarının PET/BT bulgularını evre ayırt etmeksizin inceledik.

KHDAK hastalarında klinik evreler arasında LEGÇ, SUVmax, SUVmean, MTV ve TLG yönünden anlamlı farklılık saptandı. LEGÇ, SUVmean, SUVmax'ın ortalama değerlerinin ve MTV ile TLG'nin medyan değerlerinin evre 1 den evre $3 B$ ye doğru artış gösterdiğini saptadık. Çalışmamıza benzer şekilde Cerfolio et al. (7) 315 KHDAK'lı hastayı kapsayan çalışmalarında TNM evrelemesine göre evre I-IV arasındaki hastalarda SUVmax değerinin farklı olduğunu ve bu farklılığın istatistiksel açıdan anlamlı olduğunu bulmuşlardır. Ancak çalışmamızda evre 4 tümörlerin LEGÇ, SUVmax, SUVmean, MTV, TLG değerlerinin evre 3B tümörlerden daha düşük

Tablo 2. KHAK Hastalarının Evreye Göre PET/BT Parametreleri

\begin{tabular}{|c|c|c|c|c|c|c|}
\hline Khak & $\begin{array}{l}\text { Hasta } \\
\text { Sayısı } \\
(n)\end{array}$ & $\begin{array}{l}\text { LEGÇ }(\mathrm{mm}) \\
\text { Ortalama } \\
\text { Standart } \\
\text { Sapma }\end{array}$ & $\begin{array}{l}\text { SUVmax }(\mathrm{g} / \mathrm{ml}) \\
\text { Ortalama } \\
\text { Standart } \\
\text { Sapma }\end{array}$ & $\begin{array}{l}\text { SUVmean }(\mathrm{g} / \mathrm{ml}) \\
\text { Ortalama } \\
\text { Standart } \\
\text { Sapma }\end{array}$ & $\begin{array}{l}\text { MTV }(\mathrm{ml}) \\
\text { Median } \\
(\% 25-\% 75)\end{array}$ & $\begin{array}{c}\text { TLG(g) } \\
\text { Median } \\
(\% 25-\% 75)\end{array}$ \\
\hline Sınırlı Evre & 16 & $\begin{array}{c}60,00 \\
\pm \\
16,38\end{array}$ & $\begin{array}{c}15,35 \\
\pm \\
7,55\end{array}$ & $\begin{array}{c}7,59 \\
\pm \\
3,60\end{array}$ & $\begin{array}{c}89,60 \\
(49,96-147,65)\end{array}$ & $\begin{array}{c}587,64 \\
(369,47-1033,21)\end{array}$ \\
\hline Yaygın Evre & 8 & $\begin{array}{l}55,13 \\
\pm \\
12,81 \\
0,471^{*}\end{array}$ & $\begin{array}{c}15,29 \\
\pm \\
9,50 \\
0,986^{*}\end{array}$ & $\begin{array}{c}8,62 \\
\pm \\
4,59 \\
0,555^{*}\end{array}$ & $\begin{array}{c}75,30 \\
(52,23-102,61) \\
0,569^{* *}\end{array}$ & $\begin{array}{c}551,43 \\
(305,35-989,50) \\
0,976^{* *}\end{array}$ \\
\hline
\end{tabular}


Tablo 3. KHDAK Hastalarının Evrelere Göre PET/BT Parametreleri

\begin{tabular}{|c|c|c|c|c|c|c|}
\hline & $\begin{array}{l}\text { Sayı } \\
\text { (n) }\end{array}$ & $\begin{array}{c}\text { LEGÇ } \\
\text { (mm) } \\
\text { Ortalama } \\
\pm \\
\text { Standart } \\
\text { Sapma }\end{array}$ & $\begin{array}{c}\text { SUVmax } \\
(\mathrm{g} / \mathrm{ml}) \\
\text { Ortalama } \\
\pm \\
\text { Standart } \\
\text { Sapma }\end{array}$ & $\begin{array}{c}\text { SUVmean } \\
\text { (g/ml) } \\
\text { Ortalama } \\
\pm \\
\text { Standart } \\
\text { Sapma }\end{array}$ & $\begin{array}{l}\text { MTV }(\mathrm{ml}) \\
\text { Median } \\
(\% 25-\% 75)\end{array}$ & $\begin{array}{l}\text { TLG(g) } \\
\text { Median } \\
(\% 25-\% 75)\end{array}$ \\
\hline \multicolumn{7}{|c|}{ T Evre } \\
\hline T1 & 12 & $19,08 \pm 5,12$ & $7,36 \pm 3,51$ & $4,13 \pm 1,73$ & $\begin{array}{c}2,97 \\
(0,92-6,36)\end{array}$ & $\begin{array}{c}14,29 \\
(2,72-26,07)\end{array}$ \\
\hline T2 & 18 & $38,50 \pm 10,53$ & $12,41 \pm 5,43$ & $6,41 \pm 2,26$ & $\begin{array}{c}36,40 \\
(18,79-50,03)\end{array}$ & $\begin{array}{c}230,59 \\
(103,21-449,63)\end{array}$ \\
\hline T3 & 35 & $57,22 \pm 17,42$ & $16,31 \pm 4,39$ & $8,20 \pm 2,02$ & $\begin{array}{c}61,20 \\
(33,20-158,55)\end{array}$ & $\begin{array}{c}504,39 \\
(257,10-1158,74)\end{array}$ \\
\hline $\mathrm{T} 4$ & 41 & $64,04 \pm 21,59$ & $17,50 \pm 6,55$ & $8,34 \pm 2,88$ & $\begin{array}{c}124,30 \\
(39,70-124,30)\end{array}$ & $\begin{array}{c}1085,86 \\
(294,95-1641,40)\end{array}$ \\
\hline $\begin{array}{l}P \mathrm{~d} \\
\mathrm{NE}\end{array}$ & & $<0,001^{*}$ & $<0,001^{*}$ & $<0,001^{*}$ & $<0,001^{* *}$ & $<0,001^{* *}$ \\
\hline No & 18 & $36,22 \pm 22,90$ & $10,62 \pm 5,57$ & $5,49 \pm 2,70$ & $\begin{array}{c}24,70 \\
(2,71-44,63)\end{array}$ & $\begin{array}{c}164,54 \\
(6,91-397,46)\end{array}$ \\
\hline N1 & 18 & $38,50 \pm 20,22$ & $13,36 \pm 5,99$ & $6,66 \pm 2,36$ & $\begin{array}{c}25,85 \\
(8,14-48,88)\end{array}$ & $\begin{array}{c}132,79 \\
(37,15-449,63)\end{array}$ \\
\hline N2 & 32 & $58,03 \pm 19,51$ & $16,62 \pm 5,82$ & $8,54 \pm 2,40$ & $\begin{array}{c}58,52 \\
(28,40-156,40)\end{array}$ & $\begin{array}{c}476,75 \\
(275,45-1260,41)\end{array}$ \\
\hline N3 & 38 & $61,81 \pm 19,50$ & $16,75 \pm 6,08$ & $7,94 \pm 2,69$ & $\begin{array}{c}120,00 \\
(40,08-175,60)\end{array}$ & $\begin{array}{c}721,32 \\
(301,04-1360,80)\end{array}$ \\
\hline $\begin{array}{l}\mathrm{P} d \\
\text { Klin }\end{array}$ & $\begin{array}{l}\text { ri } \\
\text { Evre }\end{array}$ & $<0,001^{*}$ & $0,001^{*}$ & $<0,001^{*}$ & $<0,001^{* *}$ & $<0,001^{* *}$ \\
\hline 1 & 11 & $\begin{array}{l}22,81 \\
\pm \\
10,98\end{array}$ & $\begin{array}{l}7,19 \\
\pm \\
3,63\end{array}$ & $\begin{array}{l}3,88 \\
\pm \\
1,91\end{array}$ & $\begin{array}{c}2,76 \\
(0,77-14,70)\end{array}$ & $\begin{array}{c}8,61 \\
(1,66-46,16)\end{array}$ \\
\hline 2 & 13 & $\begin{array}{c}31,38 \\
\pm \\
11,01\end{array}$ & $\begin{array}{c}11,69 \\
\pm \\
4,67\end{array}$ & $\begin{array}{l}6,07 \\
\pm \\
2,08\end{array}$ & $\begin{array}{c}18,60 \\
(6,67-39,00)\end{array}$ & $\begin{array}{c}92,86 \\
(28,49-226,54)\end{array}$ \\
\hline $3 A$ & 23 & $\begin{array}{l}51,56 \\
\pm \\
18,46\end{array}$ & $\begin{array}{l}15,23 \\
\pm \\
3,57\end{array}$ & $\begin{array}{l}8,17 \\
\pm \\
1,76\end{array}$ & $\begin{array}{c}37,50 \\
(24,80-76,80)\end{array}$ & $\begin{array}{c}336,29 \\
(252,57-642,53)\end{array}$ \\
\hline $3 B$ & 21 & $\begin{array}{c}64,42 \\
\pm \\
19,00\end{array}$ & $\begin{array}{c}18,47 \\
\pm \\
7,62\end{array}$ & $\begin{array}{l}8,69 \\
\pm \\
3,13\end{array}$ & $\begin{array}{c}134,80 \\
(54,86-172,50)\end{array}$ & $\begin{array}{c}1164,85 \\
(672,52-2001,66)\end{array}$ \\
\hline$P d$ & 38 & $\begin{array}{c}61,92 \\
\pm \\
20,18 \\
<0,001^{*}\end{array}$ & $\begin{array}{c}16,60 \\
\pm \\
5,57 \\
<0,001^{*}\end{array}$ & $\begin{array}{l}7,94 \\
\pm \\
2,45 \\
<0,001^{*}\end{array}$ & $\begin{array}{c}96,40 \\
(38,15-178,10) \\
<0,001^{* *}\end{array}$ & $\begin{array}{c}616,28 \\
(263,12-1486,82) \\
<0,001^{* *}\end{array}$ \\
\hline
\end{tabular}

olduğu saptandı. Klinik evrelemede evre 4 tümörleri diğer evrelerden ayıran asıl belirleyici faktör tümörün metastaz yapmasıdır. Bazı tümörlerde erken dönemde bile metastaz olabileceği bu durumu açıklamaktadır.

$\mathrm{Li}$ et al. (8) TNM evrelemesine göre evre I-IV arasında ve hepsi klinik olarak T1 kategorisinde olan değişik histolojik alt tiplerdeki 107 KHDAK hastayı içeren çalışmalarının sonucunda evre ilerledikçe SUVmax değerinin artığını ve evreler arasındaki bu
SUVmax artışının istatistiksel olarak anlamlı olduğunu bulmuştur. Primer tümörün MTV ve TLG değerlerinin akciğer kanserinde klinik evre ile yakından ilişkili olduğu ve bu parametrelerin daha yüksek oluşunun uzak metastaz riski ile sonuçlandığı yakın tarihli bir çalışmada da vurgulanmıştır (14). Şahiner et al. (15) yaptığı çalışmada KHDAK hastalarının farklı klinik evreleri arasında LEGÇ, SUVmax, MTV ve TLG değerlerinin istatistiksel açıdan anlamlı fark 
Tablo 4. Akciğer Kanserli Hasta Gruplarında PET/BT Kantitatif değerleri

\begin{tabular}{|c|c|c|c|c|c|c|}
\hline & $\begin{array}{l}\text { Hasta } \\
\text { Sayısı } \\
\text { (n) }\end{array}$ & $\begin{array}{l}\text { LEGÇ }(\mathrm{mm}) \\
\text { Ortalama } \pm \\
\text { Standart } \\
\text { Sapma }\end{array}$ & $\begin{array}{c}\text { SUVmax }(\mathrm{g} / \mathrm{ml}) \\
\text { Ortalama } \pm \\
\text { Standart } \\
\text { Sapma }\end{array}$ & $\begin{array}{c}\text { SUVmean }(\mathrm{g} / \mathrm{ml}) \\
\text { Ortalama } \pm \\
\text { Standart } \\
\text { Sapma }\end{array}$ & $\begin{array}{c}\text { MTV(ml) } \\
\text { Median } \\
(\% 25-\% 75)\end{array}$ & $\begin{array}{c}\text { TLG }(g) \\
\text { Median } \\
(\% 25-\% 75)\end{array}$ \\
\hline \multirow[t]{2}{*}{ KHDAK } & 106 & 52,37 & 15,10 & 7,49 & 59,72 & 458,13 \\
\hline & & $22^{ \pm} 75$ & $\begin{array}{c} \pm \\
6,29\end{array}$ & $\begin{array}{l} \pm \\
2,75\end{array}$ & $(30,45-144,70)$ & $(59,32-1158,72)$ \\
\hline \multirow[t]{2}{*}{ KHAK } & 24 & 58,38 & 15,33 & 7,93 & 62,50 & 400,75 \\
\hline & & $\stackrel{ \pm}{ \pm}$ & $\begin{array}{c} \pm \\
8.04\end{array}$ & $\begin{array}{l} \pm \\
3.89\end{array}$ & $(8,82-164,50)$ & $(50,25-1131,29)$ \\
\hline P değeri & & $0,12^{*}$ & $0,88^{*}$ & $0,52^{*}$ & $0,17^{* *}$ & $0,24^{* *}$ \\
\hline
\end{tabular}

oluşturduğu bulunmuştur. Hyun et al. (10) erken evre (evre 1 ve 2) KHDAK olan 529 hasta üzerinde yaptıkları çalışmada; çok değiş̧enli analizlerde, MTV ve TLG değerlerinin tümör evresi, tümör histolojisi ve ameliyat tipinden bağımsız olarak artmış rekürrens ve ölüm riski ile bir ilişkisi olduğunu saptamışlardır. Meloni et al. (16) KHDAK olan erken evre hastalarda yapılan başka bir çalışmada ise TLG değerinin lokal rekürrensleri gösteren bağımsız bir değişken olduğunu saptamışlardır. Chen et al. (17) KHDAK olan 105 hasta üzerinde yaptıkları çalışmada, tüm vücut TLG değerinin prognostik öngörü açısından

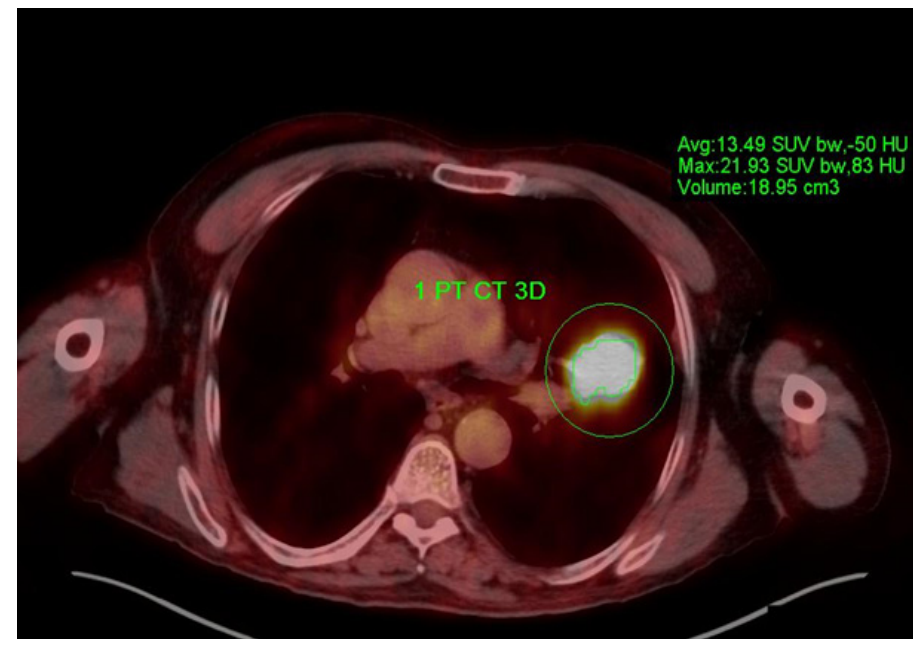

Şekil 1. Sol akciğer üst lobdaki kitleden yassı hücreli akciğer kanseri tanısı alan 62 yaşında erkek olgunun metabolik parametreleri; SUVmax: 21.93, SUVmean: 13.49, MTV: $18.95 \mathrm{ml}$ ve TLG: $255.64 \mathrm{~g}$ olarak bulunmuştur. SUVmax, maksimum standardize alım değeri; SUVmean, ortalama standardize alım değeri; MTV, metabolik tümör hacimi; TLG, toplam lezyon glikolizisi.
TNM evresinden daha iyi bir belirteç olabileceğini önermişlerdir. Bu çalışmalara aksi yönde olarak Dooms et al. (18) primer akciğer tümörünün FDG tutulumu ile TNM evresi arasında ilişki saptamamışlardı. Aynı bağlamda, Hoang et al. (19) tarafından evre III-IV arası, 214 KHDAK hastasıyla yapılan retrospektif bir çalışmada da hastaların primer tümör SUVmax değeri ortalaması 11,1 olup bu değerin altında ve üstünde olan hastaların sağ kalım açısından anlamlı farklılık göstermediği saptanmıştır.

Küçük hücreli dışı akciğer kanserinde farklı T evreleri arasında yapılan çalışmalarda; Li et al. (8) değişik histolojilerde, evre I-IV arasında 107 KHDAK hastayı retrospektif olarak incelemiş olup tümör boyutu ile SUVmax arasında pozitif korelasyon saptamışlardır. Çalışmamıza benzer şekilde yapılan başka bir çalışmada LEGÇ, SUVmax, MTV ve TLG değerleri yönünden farklı T evreleri arasında anlamlı farklılık bulunmuştur (15). Yukardaki çalışmalara benzer şekilde tümör boyutu ile SUVmax arasında pozitif korelasyon olduğunu gösteren başka çalışmalarda vardır (7). Bununla beraber bazı araştırmacılarda aksi yönde, yani tümör boyutu ile SUVmax değeri arasında korelasyon olmadığını gösteren veriler elde etmişlerdir (20). Çalışmamızda ise LEGÇ, SUVmax, SUVmean, MTV, TLG yönünden farklı T evreleri arasında anlamlı farklılık izlenmiş olup LEGÇ, SUVmean, SUVmax'in ortalama değerlerinin ve MTV ile TLG'nin medyan değerlerinin T1 evreden T3 evreye doğru artış gösterdiği saptandı. T3 ve T4 evre tümörlerde ise birbirine yakın değerler olduğu saptandı. T evreleri ile ilgili bu bulguların nedeninin T1, T2 ve T3 evrelemede asıl belirleyici faktörlerin çoğunlukla boyut olmasına karşın T4 evrede boyut dışı etkenlerin devreye girmesi olduğu düşünülmüştür. Çalışmamızda, KHDAK hastalarında farklı N evreleri 
arasında LEGÇ, SUVmax, SUVmean, MTV ve TLG yönünden anlamlı farklılık saptandı. N evreleri arasında N0 dan N3 evreye doğru gidildikçe LEGÇ, SUVmax, MTV ve TLG ortalama değerleri artış göstermektedir. Bulgularımızla benzer şekilde primer tümörün SUVmax değeri ile $\mathrm{N}$ evreleri arasında (N0'dan N3 evreye doğru gidildikçe) istatistiksel yönden anlamlı bir farklılık olduğunu gösteren çalışmalar vardır (7, 8, 21-23). Örneğin, Zhu et al. $(22,23)$ tarafından yapılan çalışmada ve Yıldırım et al. yaptığı çalışmada, primer tümörün SUVmax değeri arttıkça, tümörün lokal yayılımının ve metastaz kapasitesinin arttığı bulunmuştur.

Küçük hücreli akciğer kanseri hastaları ayrı olarak incelendiğinde sınırlı evre ile yaygın evre KHAK hastaları arasında LEGÇ, SUVmax, SUVmean, MTV, TLG, yönünden anlamlı farklılık saptanmadı. Çalışmamıza benzer şekilde yapılan başka bir çalışmada da sınırlı evre ileyaygın evre KHAK hastaları arasında LEGÇ, SUVmax, MTV ve TLG değerleri arasında anlamlı farklılık saptanmamıştır (15). Aksi yönde yapılan bir çalışmada Lee et al. (24) 76 sınırlı ve yaygın evre KHAK hastasının verilerini incelemiş ve her iki evrede de yüksek SUVmax değerlerinin kısa sağ kalım süresi ile ilişkili olduğunu belirtmişlerdir. Zhu et al. (25) tarafından yapılan başka bir çalışmada ise, MTV ve TLG hem sınırlı evre hem de yaygın evre KHAK'lı hastalarda progresyon ve sağkalım açısından önemli prognostik faktörler olarak bulunmasına rağmen primer tümörün SUVmax değerinin sağ kalım ile ilişkisi bulunmamıştır. Bizim çalışmamızda sınırlı evre ile yaygın evre KHAK hastaları arasında metabolik aktivite farkı görmememizin nedeni hasta sayısının azlığından kaynaklanıyor olabilir.

Çalışmamızda LEGÇ, SUVmean, SUVmax'ın ortalama değerlerinde ve MTV ile TLG'nin medyan değerlerinde KHAK ile KHDAK hasta grupları arasında anlamlı farklılık saptanmadı. Şahiner et al. (15) yaptığı çalışmada da çalışmamıza benzer şekilde KHAK ile KHDAK hasta grupları arasında PET/BT paramatreleri arasında anlamlı farklılık saptanmamıştır. Çalışmamızın retrospektif olması, KHAK hastalarının diğer çalışmalara göre toplam hasta sayısının az olması, KHDAK hastalarının TNM evreleme sistemine göre evrelerinin heterojen dağılım göstermesi, tümörlerin histopatolojik alt tiplerinin heterojen dağılması ve sayılarının yetersiz olması çalışmamızı kısıtlamaktadır. Ayrıca PET/ BT görüntülerinden MTV ve TLG değerlerinin hesaplanmasında kullandığımız tümörün ilgi alanının çizilmesi yönteminin manuel yapılması gibi zorlukların ve kişiden kişiye değişebilecek sonuçların yeni geliştirilecek yazılımlar sayesinde ortadan kaldırılması ile istatistiksel olarak daha güvenilir sonuçlara ulaşılabileceği kanaatindeyiz.

\section{SONUÇ}

Sonuç olarak çalışmamızda, KHDAK hastalarında primer tümörün daha yüksek SUVmax, SUVmean, MTV ve TLG değerlerinin daha ileri klinik evreyi predikte ettiği saptandı. Bu parametrelerin prognostik değer olarak kullanılıp kullanılamayacağını görmek için daha fazla sayıda hastayla yapılan prognoza yönelik prospektif ve çok merkezli yeni çalışmalara intiyaç bulunmaktadır.

Çıkar Çatışması: Çalışmada herhangi bir çıkar çatışması yoktur.

Finansal Çıkar Çatışması: Çalışmada herhangi bir finansal çıkar çatışması yoktur.

Yazışma Adresi: Mustafa Erol, Sağlık Bilimleri Üniversitesi, Konya Eğitim ve Araştırma Hastanesi, Nükleer Tıp Birimi, Konya, Türkiye

Tel: +905317972611

Email: mustafaerol82@hotmail.com

\section{KAYNAKLAR}

1. Goldstraw P, Crowley J, Chansky K, et al. The IASLC Lung Cancer Staging Project: Proposals for the revision of the TNM stage groupings in the forthcoming (seventh) edition of the TNM Classification of malignant tumours. JTO 2007;2(8):706-14.

2. Shepherd FA, Crowley J, Van Houtte P, et al. The International Association for the Study of Lung Cancer lung cancer staging project: Proposals regarding the clinical staging of small cell lung cancer in the forthcoming (seventh) edition of the tumor, node, metastasis classification for lung cancer. JTO 2007;2(12):1067-77.

3. Birim Ö, Kappetein AP, Van Klaveren R, et al. Prognostic factors in non-small cell lung cancer surgery. EJSO 2006;32(1):12-23.

4. Duhaylongsod FG, Lowe VJ, Patz Jr EF, et al. Lung tumor growth correlates with glucose metabolism measured by fluoride-18 fluorodeoxyglucose positron emission tomography. Annals of Thor Surg 1995;60(5):1348-52.

5. Younes M, Brown RW, Stephenson M, et al. Overexpression of Glut1 and Glut3 in stage I nonsmall cell lung carcinoma is associated with poor survival. Cancer 1997;80(6):1046-51.

6. Ahuja V, Coleman RE, Herndon J, et al. The prognostic significance of fluorodeoxyglucose positron emission tomography imaging for patients with nonsmall cell lung carcinoma. Cancer 1998;83(5):918-24.

7. Cerfolio RJ, Bryant AS, Ohja B, et al. The maximum standardized uptake values on positron emission tomography of a non-small cell lung cancer predict stage, recurrence, and survival. J Thorac Cardiovasc Surg 2005;130(1):151-9.

8. Li M, Liu N, Hu M, et al. Relationship between primary tumor fluorodeoxyglucose uptake and nodal or distant metastases 
at presentation in T1 stage non-small cell lung cancer. Lung Cancer 2009;63(3):383-6.

9. Liao S, Penney BC, Wroblewski K, et al. Prognostic value of metabolic tumor burden on 18 F-FDG PET in nonsurgical patients with non-small cell lung cancer. Eur $\mathrm{J}$ Nucl 2012;39(1):27-38.

10. Hyun SH, Choi JY, Kim K, et al. Volume-based parameters of 18F-fluorodeoxyglucose positron emission tomography/ computed tomography improve outcome prediction in earlystage non-small cell lung cancer after surgical resection. Ann Surg 2013;257(2):364-70.

11. Bray F, Ferlay J, Soerjomataram I, et al. Global cancer statistics 2018: GLOBOCAN estimates of incidence and mortality worldwide for 36 cancers in 185 countries. CA: Cancer J Clin 2018;68(6):394-424.

12. Miwa K, Inubushi M, Takeuchi $\mathrm{Y}$, et al. Performance characteristics of a novel clustered multi-pinhole technology for simultaneous high-resolution SPECT/PET Ann Nucl Med 2015;29(5):460-6.

13. Chang $\mathrm{H}$, Lee SJ, Lim J, et al. Prognostic significance of metabolic parameters measured by 18 F-FDG PET/CT in limited-stage small-cell lung carcinoma. J Cancer Res Clin Oncol 2019;145(5):1361-7.

14. Hu WD, Wang $H$, Wang $Y B$, et al. Correlation study on 18F-FDG PET/CT metabolic characteristics of primary lesion with clinical stage in lung cancer. TQ J Nucl Med Mol Imaging 2019.

15. Sahiner I, Atasever T, Akdemir U, et al. Relationship between primary lesion metabolic parameters and clinical stage in lung cancer. Rev Esp Med Nucl Imagen Mol 2013;32(6):35763.

16. Melloni G, Gajate A, Sestini S, et al. New positron emission tomography derived parameters as predictive factors for recurrence in resected stage I non-small cell lung cancer. EJSO 2013;39(11):1254-61.

17. Chen HH, Chiu N-T, Su W-C, et al. Prognostic value of wholebody total lesion glycolysis at pretreatment FDG PET/CT in non-small cell lung cancer. Radiology 2012;264(2):559-66.
18. Dooms C, van Baardwijk A, Verbeken E, et al. Association between 18F-fluoro-2-deoxy-D-glucose uptake values and tumor vitality: prognostic value of positron emission tomography in early-stage non-small cell lung cancer. JTO 2009;4(7):822-8.

19. Hoang JK, Hoagland LF, Coleman RE, et al. Prognostic value of fluorine-18 fluorodeoxyglucose positron emission tomography imaging in patients with advanced-stage nonsmall-cell lung carcinoma. JTO 2008;26(9):1459-64.

20. Eschmann S, Friedel G, Paulsen F, et al. Is standardised 18 F-FDG uptake value an outcome predictor in patients with stage III non-small cell lung cancer? Eur J Nucl 2006;33(3):263-9.

21. Sachs S, Bilfinger TV, Komaroff $E$, et al. Increased standardized uptake value in the primary lesion predicts nodal or distant metastases at presentation in lung cancer. Clin Lung Cancer 2005;6(5):310-3.

22. Yıldırım F, Türk M, Akdemir ÜÖ, et al. Küçük hücreli dışı akciğer kanserinde primer tümör metabolik aktivitesi ile lenf nodu ve uzak organ metastazı arasındaki ilişki. GMJ 2018;29:164-8.

23. Zhu S-H, Zhang Y, Yu Y-H, et al. FDG PET-CT in non-small cell lung cancer: Relationship between primary tumor FDG uptake and extensional or metastatic potential. Asian Pac J Cancer Prev 2013;14(5):2925-9.

24. Lee YJ, Cho A, Cho BC, et al. High tumor metabolic activity as measured by fluorodeoxyglucose positron emission tomography is associated with poor prognosis in limited and extensive stage small-cell lung cancer. Clin Cancer Res 2009;15(7):2426-32.

25. Zhu D, Ma T, Niu Z, et al. Prognostic significance of metabolic parameters measured by $18 \mathrm{~F}$-fluorodeoxyglucose positron emission tomography/computed tomography in patients with small cell lung cancer. Lung Cancer 2011;73(3):332-7. 